Edutech, Tahun 13, Vol.1, No.1, Februari 2014

\title{
FUNGSI HUMAS PEMERINTAH KABUPATEN SUMEDANG DALAM MENGKAMPANYEKAN SUMEDANG SEBAGAI PUSEUR BUDAYA SUNDA (SPBS)
}

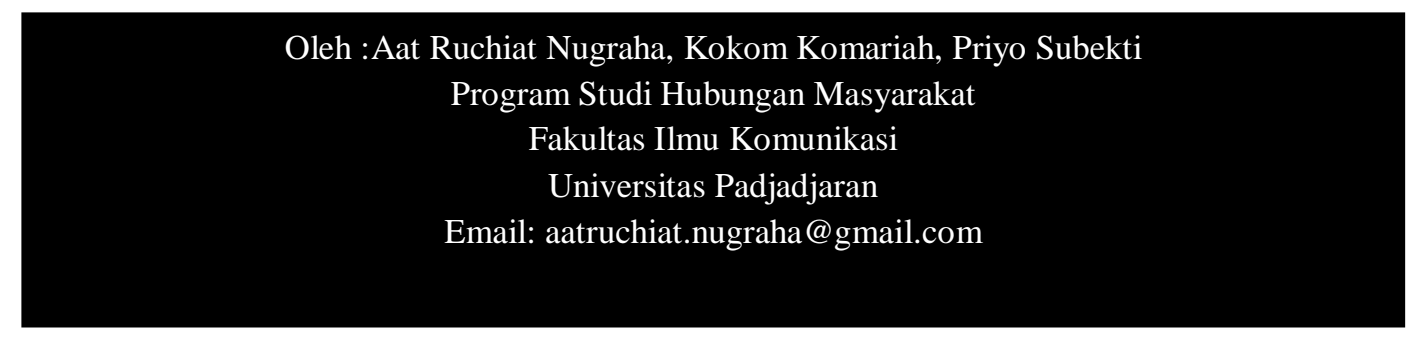

Abtract, Regional autonomy gives opportunity to the leadership of the district/city to build a territory independently and energized. Sumedang as an autonomous region PR utilize the functionality of territory in the development process in order to improve or maintain the perception, image and reputation of both material and immaterial development of the public. The technique of communications made Sumedang Government Relations ie through the use of a public campaign to strengthen city branding as a cultural center in West Java.

\section{Key Word: Rigional Autonomy, Public Relations Function and City Branding}

Abstrak, Adanya otonomi daerah memberikan peluang kepada pimpinan kabupaten/kota untuk membangun wilayahnya secara mandiri dan berdayasaing. Sumedang sebagai daerah otonomi memanfaatkan fungsi Humas pada proses pembangunan wilayahnya dalam rangka meningkatkan maupun mempertahankan persepsi, citra dan reputasi pembangunan secara materi maupun immateri dari publiknya. Adapun teknik komunikasi yang dilakukan Humas Pemerintah Kabupaten Sumedang yaitu melalui pemanfaatan kampanye publik dalam menguatkan city branding sebagai pusat budaya di Jawa Barat.

Kata Kunci: Otonomi Daerah, Fungsi Humas dan Citra Kota

\section{A. PENDAHULUAN}

Keberhasilan suatu lembaga

terletak pada kemampuannya

beradaptasi terhadap berbagai

perubahan yang muncul di lingkungan.

Pemberdayaan segala potensi yang

dimiliki oleh suatu lembaga merupakan

modal untuk mencapai suatu kemajuan.

Unsur budaya yang dimiliki oleh

lembaga pemerintahan, khususnya dapat dijadikan sebagai landasan dalam membuat suatu kebijakan yang dapat mensejahterakan dan membanggakan bagi masyarakatnya.

Pemerintah Kabupaten Sumedang sebagai salah satu unsur pemerintahan mencoba menggulirkan suatu kebijakan mengenai budaya yang dapat menunjang sektor pembangunan kedaerahan. Kebijakan tersebut berupa 
Edutech, Tahun 13, Vol.1, No.1, Februari 2014

implementasi pembangunan untuk daerah lain yang menjadikan daerah Sumedang sebagai menggunakan bahasa Puseur Budaya Sunda (SPBS) yang dapat membentuk identitas, citra dan reputasi pemerintah yang mampu bersaing dan beradaptasi terhadap perubahan lokal, nasional, regional dan internasional. Sumedang merupakan salah satu kota di Jawa Barat, yang memiliki slogan Sumedang Tandang Nyandang Kahayang, memiliki berbagai hal yang dapat dijual atau diperlihatkan dalam lingkup budaya sehingga beberapa alasan yang tepat ketika dikatakan Sumedang sebagai Puser Budaya Sunda (SPBS) yaitu:

1. Mahkota binokasih yang merupakan mahkota kerajaan sunda berada di Sumedang atau dalam istilah lain, Sumedang merupakan pusat pemerintahan kerajaan Sunda sehingga pantas dikatakan bahwa Sumedang menjadi puseur budaya Sunda;

2. Sumedang merupakan daerah yang masih menggunakan bahasa sunda sebagai bahasa sehari-hari berbeda dengan

Indonesia, yang paling terlihat yaitu dari para pelajar umumnya para pelajar sumedang berkomunikasi dengan bahasa sunda sedangkan para pelajar di daerah lain jarang sekali menggunakan bahasa sunda;

3. Sumedang merupakan daerah yang memiliki budaya yang beraneka ragam, seperti upacara dalam bercocok tanam yang melahirkan sebuah seni tarawangsa, dari upacara sunatan lahir kesenian dog-dog, kuda renggong dan masih banyak yang lain, serta dari segi budaya yang lainnya seperti goong renteng, tari umbul, tayuban, bangreng dan yang lain;

4. Sumedang melahirkan tokohtokoh dalam budaya sunda seperti Alm. Saleh Danasasmita, Alm. Makmur Danasasmita, Prof. Saini Kosim, Alm. Rd. Angga 
Edutech, Tahun 13, Vol.1, No.1, Februari 2014

Kusumadinata, Anm. Jenderal Sesungguhnya hal inilah yang Wirahadikusumah mantan diinginkan Pemerintah Kabupaten wakil presiden RI dan para Sumedang, ketika lembaga ini tokoh lainnya; dan

dihadapkan pada sebuah tuntutan untuk

5. Lahirnya tokoh muda yang berasal dari sumedang seperti melaksanakan amanat undang-undang Lili Suparli S.Kar., M.Hum., tentang otonomi daerah dalam upaya Asep Zatnika, S.Sen., mensejahterakan masyarakatnya.

M.Hum., Dindin, dan banyak

Berkaitan dengan program yang lain nya yang mengembangkan budaya Sunda.

Keberanian Pemerintah Kabupaten Sumedang terhadap kebijakan Sumedang sebagai Puseur Budaya Sunda (SPBS), maka peran dan fungsi Humas Pemerintah Kabupaten Sumedang semakin dibutuhkan dalam upaya untuk membangun suasana yang kondusif, identitas, citra, dan reputasi mengdeklarasikan daerahnya sebagai daerah Sumedang, melalui teknikpuseur (pusat) budaya Sunda (SPBS) di teknik komunikasi tertentu (kampanye) Jawa Barat ini, tentunya membawa yang disampaikan pada konsekuensi terhadap berbagai elemen stakeholdersnya. Disamping itu, masyarakat maupun pemerintah dalam Humas Pemerintah sebagai pelaksana mengemban amanah tersebut untuk komunikasi pemerintahan dapat mewujudkannya. Salah satu bentuk menjalankan keleluasaan yang tinggi partisipasi masyarakat dalam dalam mempertimbangkan dan mengkampanyekan Sumedang sebagai menterjemahkan kebijakan tersebut Puseur Budaya Sunda (SPBS) ini, yaitu yang dikombinasikan dengan keterlibatan mereka dalam berbagai pandangan-pandangan stakeholders macam kegiatan seni dan budaya baik yang dapat mempengaruhi citra dan yang diselenggarakan oleh Pemerintah reputasi lembaga. Dengan demikian, Kabupaten Sumedang maupun atas kinerja Humas Pemkab Sumedang inisiatif dari mereka sendiri. dalam melaksanakan kampanye 
Edutech, Tahun 13, Vol.1, No.1, Februari 2014

kehumasan khususnya, dituntut untuk dapat menjadi inovator, fasilitator dan agent development dalam mengkomunikasikan berbagai macam kebijakan pemerintahnya, khususnya tentang Sumedang sebagai Puseur Budaya Sunda (SPBS) ke berbagai stakeholders yang ada di wilayah Sumedang, Jawa Barat dan tingkat Nasional.

Sekarang ini Humas Pemerintah dituntut untuk bisa manghadapi dan mempunyai fungsi yang beragam (kreatif) dalam mengemas pesan maupun ketika menjadi komunikator yang handal apalagi setelah diberlakukannya UU KIP, maka fungsi dan peran humas harus lebih professional dalam menghadapi berbagai macam publiknya. Dengan demikian, kepentingan Humas dalam sistem pemerintahan akan lebih terlihat jelas dengan adanya penerapan otonomi daerah. Sebab, dalam sistem pemerintahan seperti itu akan memberikan suatu kesempatan bagi profesi Humas Pemerintah untuk menunjukkan peran dan fungsinya sebagai "panca indera" nya suatu lembaga/organisasi, khususnya dalam tanggung jawab bersama mewujudkan pembangunan seni budaya di wilayah kabupaten Sumedang.

\section{Perumusan Masalah}

Berdasarakan latar belakang penelitian diatas dapat dirumuskan permasalahan "Bagaimana fungsi Humas Pemerintah Kabupaten Sumedang dalam Mengkampanyekan Sumedang sebagai Puseur Budaya Sunda (SPBS)?

\section{Identifikasi Permasalahan}

Berdasarkan perumusan masalah tersebut, kemudian diidentifikasikan ke dalam pertanyaan-pertanyaan penelitian sebagai berikut :

a. Apa latar belakang ditetapkannya Sumedang sebagai Puseur Budaya Sunda (SPBS) oleh Pemerintah Kabupaten?

b. Bagaimana peran Humas Pemerintah dalam mengkampanyekan Sumedang sebagai Puseur Budaya Sunda (SPBS)?

c. Bagaimana fungsi Humas Pemerintah dalam 
Edutech, Tahun 13, Vol.1, No.1, Februari 2014

mengkampanyekan Sumedang sebagai Puseur Budaya Sunda (SPBS)?

\section{Metode Penelitian}

Metode yang digunakan dalam penelitian ini adalah metode deskriptif, yaitu penelitian yang memaparkan situasi atau peristiwa atau penelitian observasional seperti yang dikemukakan oleh Wood (1997, dalam Rahmat, 2004:25). Lebih jauh Rahmat mengemukakan bahwa penelitian deskriptif ditujukan untuk: (1) mengumpulkan informasi aktual secara rinci yang melukiskan gejala yang ada, mengidentifikasikan masalah atau memeriksa kondisi dan praktek-praktek yang berlaku, membuat perbandingan atau evaluasi, menentukan apa yang dilakukan orang lain dalam menghadapi masalah yang sama dan belajar dari pengalaman mereka untuk menetapkan rencana dan keputusan pada waktu yang akan datang (Rakhmat, 2004:25)

Suryabrata

(1998:18-19) menjelaskan bahwa penelitian deskriptif adalah penelitian yang bermaksud untuk pencandaraan (deskripsi) mengenai situasi-situasi atau keadaan. Dengan kata lain, penelitian deskriptif adalah akumulasi data dasar dalam cara deskriptif semata-mata tidak perlu mencari atau menerangkan saling hubungan, mentest hipotesis, membuat ramalan, atau mendapatkan makna dan implikasi, walaupun penelitian yang bertujuan untuk menemukan hal-hal tersebut.

Ciri lain dari metode deskriptif ialah titik berat pada obseravsi dan suasana alamiah (naturalistik setting). Penelitian ini juga bukan menjabarkan (analitis), tetapi juga memadukan (sintetis). Bukan saja melakukan klasifikasi, tetapi juga organisasi. Salah satu kegunaan lain dari penelitian deskriptif adalah penelitian ini sangat berguna dalam melahirkan atau menciptakan teori-teori tentatif. Barangkali disinilah letak perbedaan mendasar metode deskriptif kualitatif dibandingkan dengan metode lainnya. Metode deskriptif tidak menguji teori, melainkan mencari teori. Seringkali penelitian deskriptif timbul karena suatu peristiwa yang menarik perhatian 
Edutech, Tahun 13, Vol.1, No.1, Februari 2014

peneliti, tetapi belum ada kerangka teoritis yang dapat menjelaskannya.

Ciri lain dari metode deskriptif adalah titik berat pada observasi dan suasana alamiah, dimana peneliti dipandang sebagai entitas terpisah dan tidak dapat mempengaruhi fenomena. Peneliti hanya bertindak sebagai pengamat. Ia hanya membuat kategori perilaku, mengamati fenomena, dan mencatatnya dalam catatan observasi. Dengan suasana alamiah dimaksudkan bahwa peneliti terjun ke lapangan tanpa berusaha memanipulasikan variabel karena jika itu terjadi peneliti memiliki kemungkinan untuk mempengaruhi perilaku atau gejala yang sedang diamati.

Penelitian deskriptif memerlukan kualifikasi-kualifikasi yang memadai. Pertama, peneliti harus memiliki sifat reseptif. Ia harus selalu mencari, bukan menguji. Kedua, ia harus memiliki kekuatan integratif, kekuatan untuk memadukan berbagai macam informasi yang diterimanya menjadi satu keastuan penafsiran yang tepat. Jadi, penelitian deskriptif bukan saja menjabarkan, tetapi juga memadukan.
Bukan saja klasifikasi, tetapi juga organisasi, maksudnya adalah data tersebut tidak hanya dipaparkan secara gamblang namun dipadukan disangkutpautkan dengan data lain yang berhubungan sehingga menjadi suatu temuan lapangan yang dapat menggambarkan secara jelas fenomena yang diteliti.

B. HASIL DAN PEMBAHASAN

1. Sekilas Tentang Program Sumedang sebagai Puseur Budaya Sunda

Pada tahun 2009

Kabupaten Sumedang telah dikukuhkan oleh Pemerintah Provinsi Jawa Barat sebagai Puseur Budaya Sunda, yang diharapkan dapat menjadi spirit bagi segenap komponen daerah, khususnya di Jawa Barat, untuk menguatkan jatidiri sebagai masyarakat yang memiliki budaya adiluhung melalui proses pembangunan karakter. Pemerintah Kabupaten Sumedang telah menindaklanjutinya dengan mengeluarkan Peraturan Bupati 
Edutech, Tahun 13, Vol.1, No.1, Februari 2014

Sumedang Nomor 113 Tahun 2009 tentang Sumedang Puseur Budaya Sunda (SPBS). Dengan demikian, proses pembangunan di Kabupaten Sumedang ke depan akan menempatkan modal sosial dengan basis budaya lokal sebagai modal utama pembangunan.

Sumedang Puseur Budaya Sunda yang selanjutnya disingkat SPBS adalah sebuah kebijakan inovatif untuk memfasilitasi pelestarian budaya Sunda di Kabupaten Sumedang guna memperkokoh kebudayaan Jawa Barat dan Nasional. Adapun budaya Sunda yang dimaksud adalah keseluruhan gagasan, perilaku, dan hasil karya masyarakat Sunda, baik yang bersifat fisik maupun nonfisik yang diperoleh melalui proses belajar dan adaptasi terhadap lingkungannya, yang diyakini dapat memenuhi harapan dan kebutuhan hidup masyarakat Sunda.
Kegiatan SPBS dilakukan di seluruh wilayah Kabupaten Sumedang dengan melibatkan segenap komponen masyarakat yang secara sosio kultural berkaitan dengan Sumedang yang meliputi a) wujud gagasan yaitu suatu kumpulan dari ideide, nilai-nilai, norma-norma dan peraturan yang bersifat abstrak; b) wujud perilaku yaitu suatu tindakan berpola dari manusia dalam masyarakat sebagai sebuah sistem sosial; dan c) wujud karya yaitu hasil dari aktivitas dan perbuatan manusia dalam masyarakat berupa benda-benda atau halhal yang dapat diraba, dilihat dan didokumentasikan. Beberapa kebijakan SPBS yang dilakukan secara terpadu oleh Pemkab Sumedang adalah dengan memperhatikan:

a. nilai agama;

b. tradisi, nilai, norma, etika dan hukum adat;

c. sifat kerahasiaan dan kesucian unsur-unsur 
Edutech, Tahun 13, Vol.1, No.1, Februari 2014

budaya tertentu yang dipertahankan oleh masyarakat;

d. kepentingan umum, kepentingan komunitas dan kepentingan kelompok dalam masyarakat;

e. jatidiri bangsa;

f. kemanfaatan bagi masyarakat; dan peraturan perundang-undangan.

Kebijakan SPBS tersebut dimaksudkan untuk meningkatkan perlindungan, pengembangan dan pemanfaatan budaya Sunda dalam praktik

penyelenggaraan

pemerintahan, pembangunan dan kemasyarakatan.

Sedangkan tujuannya adalah untuk memperkokoh jati diri aparatur pemerintahan daerah dan masyarakat serta menguatkan daya saing daerah menuju terwujudnya Kabupaten Sumedang Sejahtera, Agamis dan
Demokratis

(Sumedang SEHATI)

Melalui pembangunan berbasis budaya diharapkan akan terjadi penguatan harkat dan martabat manusia dalam proses pembangunan, akan lebih mencerahkan serta lebih berkeadilan dan manusiawi. Tolok ukur keberha silan dari pembangunan berbasis budaya ini tidak hanya dilihat dari kecukupan material belaka, tetapi oleh eksistensi dan menguatnya nilai-nilai budaya dan kearifan lokal dalam kehidupan. Budaya gotong royong misalnya, melalui spirit SPBS diharapkan akan lebih berkembang dan menjadi benteng utama bagi Kabupaten Sumedang untuk menjinakkan arus globalisasi maupun kapitalisme global.

\section{Latar Belakang Program Sumedang Puseur Budaya Sunda (SPBS)}


Edutech, Tahun 13, Vol.1, No.1, Februari 2014

Program SPBS ini tidak bersifat eksklusif, tetapi merupakan gerakan moral inklusif dari segenap komponen masyarakat Sumedang untuk mengantisipasi tantangan regional, nasional dan global. Agar lebih sistematis dan mempunyai kekuatan hukum, pada tahun 2009, kebijakan SPBS telah berhasil dituangkan dalam wujud Peraturan Bupati Sumedang Nomor: 113 Tahun 2009 tentang Sumedang Puseur Budaya Sunda, dan awal tahun 2010 mulai dikenalkan ke masyarakat melalui kegiatan Diseminasi Perencanaan Sumedang Puseur Budaya Sunda di seluruh warga masyarakat kecamatan di wilayah Pemerintah Kabupaten Sumedang.

Adapun nilai-nilai yang terkandung dari program SPBS meliputi:

a. Nilai Filosofis, Insun Medal Insun Madangan yang maknanya adalah setiap warga masyarakat Sumedang harus memiliki semangat dan tekad untuk memberikan sumbang pikiran dan karya nyata yang terbaik dan tanpa pamrih bagi kepentingan bangsa dan negara, kapan pun dan dimana pun berada sehingga warga Sumedang harus memiliki karakter Bhirawa Anoraga yaitu berani tapi rendah hati.

b. Nilai manajerial, Rawayan Jati Sunda yaitu jati diri yang harus dijaga oleh masyarakat Sumedang sebagai jembatan antara dalam proses penyelenggaraan pemerintahan, pembangunan dan kemasyarakatan, mulai dari fase perencanaan, pengorganisasian, pelaksanaan, sampai dengan pengawasan dan pertanggungjawaban, menuju tercapainya 
Edutech, Tahun 13, Vol.1, No.1, Februari 2014

masyarakat Sumedang

SEHATI. Adapun nilai-

nilai sosial budaya Sunda

yang berkembang di

tengah-tengah masyarakat

Sumedang yang berkaitan

dengan fase perencanaan

meliputi Sirna Ning Cipta,

Sirna Ning Rasa, dan Sirna

Ning Karsa; fase pengorganisasian meliputi

Sirna Ning Karya; fase

pelaksanaan meliputi Sirna

Ning Diri, Sirna Ning

Hirup, dan Sirna Ning

Hurip; dan fase

pengawasan

dan

pertanggungjawaban

meliputi Sirna Ning Wujud.

c. Nilai Operasional, Dasa

Marga Raharja yaitu

sepuluh perilaku atau sifat

yang harus dimiliki oleh

masyarakat Sumedang

untuk dilaksanakan dalam

praktik penyelenggaraan

pemerintahan,

pembangunan dan

kemasyarakatan, sehingga dapat memberikan daya

guna dan hasil guna.

Adapun sepuluh perilaku

tersebut adalah taqwa,

someah, surti, jembar,

brukbrak, guyub, motekar, tarapti-taliti-ati-ati, jununjucung dan punjul-luhung.

Dengan memiliki 10 (sepuluh) sifat dan perilaku sebagaimana diuraikan di atas, maka akan melahirkan suatu situasi dan kondisi kehidupan masyarakat Sumedang yang penuh dengan harmoni dan kebersamaan dalam balutan semangat "Silih Asah-Silih Asih-Silih Asuh", baik sebagai mahkluk pribadi maupun sosial. Maknanya adalah terwujudnya sistem sosial dalam kehidupan masyarakat yang didasari oleh sikap saling mengasihi, saling melindungi dan saling mengingatkan ke jalan kebaikan dan mencegah melakukan kemungkaran, serta saling mengasah untuk menjadi 
Edutech, Tahun 13, Vol.1, No.1, Februari 2014

pribadi yang bertaqwa, berilmu dan terampil.

Rencana pembangunan pusat pemerintahan Kabupaten Sumedang berbasis budaya Sunda serta isue strategis lainnya yang perlu mendapatkan perhatian serius dari semua pihak dalam rangka meningkatkan kualitas manajemen pemerintahan daerah dan desa. Tata kelola pemerintahan yang baik yang berbasis budaya (local culture led good governance) yang menempatkan peranan 3 pilar utama perubahan; yakni pemerintah, dunia usaha, dan masyarakat (government, enterprises, society) menurut proporsinya yang sesuai dengan bersandar pada prinsip-prinsip yang bersifat universal dan berbasis budaya lokal perlu disusun serta disosialisasikan dan mulai dilaksanakan oleh semua pihak dalam penyelenggaraan pemerintahan pelaksanaan pembangnan dan kehidupan kemasyarakatan. Tata kelola pemerintahan yang baik atau Good Governance, khususnya prinsip transparasi, akuntabilitas, partisipasi dan profesionalitas pada setiap jenjang struktur pemerintahan perlu terus ditingkatkan.

Untuk mencapai keberhasilan pembangunan, sejalan dengan prioritas pembangunan nasional dan provinsi, serta seiring dengan bergulirnya pembangunan berwawasan budaya dalam kerangka kebijakan Sumedang Puseur Budaya Sunda sebagai upaya kultural untuk turut menjawab berbagai isu strategis yang telah dikemukakan sebelumnya, serta dalam koridor pencapaian visi dan misi jangka menengah daerah sebagaimana tertuang dalam RPJMD Kabupaten Sumedang Tahun 2009-2013. Untuk mengefektifkan berbagai kegiatan pembangunan yang dilakukan melalui pendekatan 
Edutech, Tahun 13, Vol.1, No.1, Februari 2014

budaya serta semangat organisasi perangkat Sumedang Puseur Budaya daerah, tetapi dengan Sunda (SPBS) dilarutkan melalui berbagai kegiatan dalam batasan kebijakan sebagai berikut:

a. melalui berbagai kegiatan pada organisasi perangkat daerah secara langsung. Maksudnya adalah pendekatan dan semangat Sumedang Puseur Budaya Sunda tercantum secara langsung dalam dokumen perencanaan dan anggaran organisasi perangkat daerah sesuai dengan tugas pokok dan fungsinya masingmasing;

b. melalui berbagai kegiatan pada organisasi perangkat daerah secara tidak langsung. Maksudnya adalah pendekatan dan semangat Sumedang Puseur Budaya Sunda tidak tercantum secara langsung dalam dokumen perencanaan dan anggaran menempatkannya sebagai media pengayaan dalam pelaksanaan kegiatan;

c. melalui berbagai kegiatan diluar konstruksi dokumen perencanaan dan anggaran organisasi perangkat daerah. Maksudnya adalah pendekatan dan semangat Sumedang Puseur Budaya Sunda dilakukan melalui kerja sama antara organisasi perangkat daerah dengan masyarakat/pihak ketiga atau sepenuhnya dilakukan oleh masyarakat/pihak ketiga. Konsekuensi pembiayaan sepenuhnya bersumber dari swadaya masyarakat atau partisipasi pihak ketiga.

3. Tugas, Kedudukan dan Peranan Humas Pemerintah dalam Program Sumedang Puseur Budaya Sunda (SPBS) Dalam bidang pemerintahan, kegiatan humas 
Edutech, Tahun 13, Vol.1, No.1, Februari 2014

pemerintah selain bertjuan untuk memperoleh pengertian dan opini publik yang favourable, terutama untuk menciptakan iklim pendapat publik yang mendukung setipa kebijkasanaan pemerintah, seperti implementasi peraturan maupun perundang-undangan. Sehingga pada dasarnya, Humas Pemerintah berbeda dengan humas perusahaan/lembaga swasta lainnya. Humas di lembaga swasta memiliki struktur organisasi yang lebih ketat, sehingga peranan dalam menjalankan profesinya sangat spesifik. Sedangkan Humas pemerintah di samping bertugas menyelenggarakan dan mengkoordinasikan lalu-lintas arus informasi ke dalam dan ke luar organisasi, ia juga berfungsi sebagai penyaring dari komunikasi timbal balik dengan tujuan untuk menciptakan dan membina stabilitas sosial. Akibat dari dikotomi pemaknaan praktik peranan Humas di lapangan memberikan stigma yang kurang baik bagi posisi Humas di Pemerintahan yang dinilai bersifat statis dan kurang kreatif.

Kehumasan sangat diperlukan karena merupakan kelanjutan dari proses penetapan kebijaksanaan, pemberian pelayanan kepada masyarakat dengan sikap yang disesuaikan dengan kepentingan orang atau golongan, agar lembaga/instansi di mana Humas itu berada memperoleh kepercayaan dari publiknya, yaitu masyarakat dalam arti luas. Tugas Humas Pemerintah adalah :

a. Memberikan penerangan dan pendidikan kepada masyarakat ten-tang kebijakan, langkahlangkah, dan tindakantindakan pemerintah, serta memberikan pelayanan kepada masyarakat berupa 
Edutech, Tahun 13, Vol.1, No.1, Februari 2014

informasi yang diperlukan secara terbuka, jujur dan obyektif.

b. Memberi batuan kepada media berita (news media) berupa bahan-bahan informasi mengenai kebijakan dan langkahlangkah serta tindakan pemerintah, termasuk fasilitas peliputan kepada media berita untuk acaraacara resmi yang penting. Pemerintah merupakan sumber informasi yang penting bagi media, karena itu sikap keterbukaan informasi sangat diperlukan.

c. Mempromosikan kemajuan pembangunan ekonomi dan kebudayaan yang telah dicapai oleh bangsa kepada khalayak di dalam negeri maupun luar negeri.

d. Memonitor pendapat umum tentang kebijakan pemerintah, selanjutnya menyampaikan tanggapan masyarakat dalam bentuk feedback kepada pimpinan instansi-instansi pemerintah yang bersangkutan sebagai input.

Intinya humas bertugas untuk membawa masyarakat umum dan pemerintahan ke hubungan yang lebih harmonis. Dalam melaksanakan tugas, kedudukan dan peranan Humas Pemkab Sumedang dalam mengkampanyekan program SPBS yaitu mencoba menterjemahkan konsep-konsep SPBS ke dalam bentuk kegiatan yang lebih konkret dan implementatif serta mudah dipahami oleh masyarakat sehingga diharapkan terjalin informasi yang saling mendukung guna memajukan pembangunan yang berbasis keraifan lokal di wilayah Kabupeten Sumedang.

Menurut Setyaningrum (2008:19) bahwa tugas seorang Humas adalah memotivasi publik internal agar produktif, 
Edutech, Tahun 13, Vol.1, No.1, Februari 2014

memberikan sales after service yang artinya memberikan perhatian secara kontinyu kepada publiknya agar dapat menjadi setia hingga dapat tercipta word of mouth di masyarakat mengenai kebijakan organisasinya.

Keberadaan bagian Humas

Pemkab Sumedang secara struktural berada di Setda, khususnya di bawah tanggungjawab Asisten Pemerintahan, maka Humas Pemkab dalam melaksanakan tugas, kedudukan dan peranannya selalu bersinggungan dengan Bagian Umum Sekretariat Daerah (Setda) sebab Humas disini diharapkan dapat mengarahkan berbagai kebijakan Pemkab, khususnya mengenai SPBS terhadap lingkungannya. Disisi lain, Bagian Umum Setda biasanya bergerak untuk tujuan menjaga keseimbangan antara kinerja dan lingkungan, sehingga tercapai keserasian antara sasaran organisasi dengan tuntutan lingkungan, dan meningkatkan kesediaan lingkungan untuk menerima kehadirannya. Menurut Tondowidjojo (2004:6) bahwa tugas, kedudukan dan peranan bagian Humas secara umum adalah memberikan informasi baik berupa kebijakan organisasi yang kemudian harus disampaikan atau dikomunikasikan melalui media tertentu kepada stakeholdersnya yang bersifat terarah agar tercapai kesepahaman sebagai wujud penerimaan informasi kebijkasanaan tersebut.

Kedudukan Humas dalam lembaga pemerintah, menurut Cultip \& Center (2000) mengatakan bahwa idealnya Humas itu dimasukkan dalam staf inti, langsung berada di bawah pimpinan (decision maker), atau top managers, supaya lebih mampu menjalankan tugasnya. Sehingga Humas itu dapat 
Edutech, Tahun 13, Vol.1, No.1, Februari 2014

berfungsi sebagai saluran langsung dari lingkungan di mana terjadi proses pengambilan keputusan kepada masyarakat agar keputusan yang dibuat itu dipahami dan diterima. Selain itu, Humas juga bertugas menampung suarasuara atau tanggapan masyarakat mengenai kebijakan dan tindakan-tindakan yang diambil oleh instansi atau lembaga yang bersangkutan. Humas pemerintah merupakan subsistem dari sistem penerangan secara keseluruhan dan merupakan bagian dari kegiatan komunikasi sosial.

Dasar pembentukkan kegiatan Humas adalah adanya anggapan bahwa jika masyarakat diberitahu masalahnya, maka masyarakat akan bersikap wajar dan bijaksana. Karena pada dasarnya masyarakat itu merupakan pihak yang tanggap dan menginginkan kebenaran. Dengan demikian, Humas harus menunjang terwujudnya tujuan organisasi dan mengusahakan agar masyarakat mau menerima dan mengakui pertanggungjawaban yang diberikan.

Kegiatan Humas pada dasarnya disengaja (deliberate) dan terencana (planned). Humas yang efektif, didasarkan pada kebijakan dan penampilan yang sesungguhnya, bertujuan untuk memenuhi kepentingan publik dan lembaga. Humas bukan kegiatan komunikasi dalam bentuk penyebaran informasi saja, tetapi harus terjadi sharing informasi, pertukaran informasi, atau komunikasi dua arah, sehingga humas merupakan bagian dari pengambilan keputusan top manajemen. Adapun kegiatan humas yang biasa dilakukan secara profesional mencakup:

a. Events adalah kegiatan humas yang terjadi dalam kerangka waktu terbatas, 
Edutech, Tahun 13, Vol.1, No.1, Februari 2014

dan jelas kapan dimulai dan berakhirnya, ditujukan untuk satu atau beberapa publik terpilih.

b. Campaigns adalah kegiatan humas yang hampir sama dengan events, namun biasanya diadakan dalam waktu yang lebih panjang dan dapat terdiri berbagai events.

c. Programs adalah kegiatan humas yang biasanya terdiri dari berbagai event, yang biasanya tidak punya batas waktu yang jelas kapan berakhirnya, karena diadakan secara berkesinambungan.

Merujuk pada definisi Harlow dalam Danandjaja (2011:103) menyatakan bahwa peran seorang Humas di dalam organisasinya adalah sebagai Counseling, reseracher, media relations, publicity, employee relations dan goverment relations. Sedangkan tugasnya adalah sebagai pengaman kebijkasanaan pemerintah, pemberi pelayanan, penyebar pesan atau informasi mengenai kebijakan hingga programprogram kerjasama secara lokal dan nasional kepada masyarakat, menjadi komunikator yang sekaligus sebagai mediator yang proaktif dalam menjembatani kepentingan instansi pemerintah serta menampung aspirasi dan memperhatikan keinginan-keinginan publiknya. Dengan demikian, institusi yang baik bagi publik adalah institusi yang mempunyai citra positif, sehingga membuat publik "meletakkan" keyakinannya pada institusi tersebut. Dari fungsi tersebut, dapat dilihat bahwa peran Humas Pemerintah itu adalah sebagai, komunikator dan mediator.

Berkaitan dengan optimalisasi layanan publik 
Edutech, Tahun 13, Vol.1, No.1, Februari 2014

prima yang berkualitas yang dilakukan oleh instansi pemerintahan, Kementerian Pendayagunaan Aparatur Negara dan Reformasi Birokrasi sebagai partner Kementerian Dalam Negeri telah menetapkan program revitalisasi kehumasan. Adapun tujuan revitalisasi kehumasan ini adalah untuk mendorong terciptanya kehumasan di instansi pemerintah yang profesional dengan memiliki indikator pencapaian kesuksesan kinerja kehumasan di bidang pemerintahan yaitu adanya standar operasional optimalisasi pelayanan publik, tercapainya opini publik yang positif, adanya sistem keakuratan, kemudahan, dan kecepatan bagi publik untuk mendapatkan informasi, serta didukung oleh adanya keterbukaan saluran komunikasi internal dan eksternal.
4. Fungsi Humas Pemerintah dalam Program Sumedang Puseur Budaya Sunda (SPBS) Tugas dan fungsi Humas pemerintah sampai sekarang ini belum tercipta. Di berbagai departemen dan lembaga nondepartemen pemerintahan tidak ada keseragaman. Jadi belum ada standarisasi di kalangan Humas-humas pemerintah. Sehingga pada dasarnya keberadaan Humas sebagai salah satu unit di lembaga pemerintahan sudah tidak bisa ditawar lagi, mengingat fungsinya yang dapat menunjang kegiatan manajemen untuk mencapai tujuan organisasi. Fungsi seorang Humas dalam dunia pemerintahan adalah membantu pemerintah untuk memasarkan program dan kebijakan yang akan dikeluarkan agar dapat diterima dengan baik oleh masyarakat, serta memiliki peran yang penting dalam 
Edutech, Tahun 13, Vol.1, No.1, Februari 2014

pelaksanaan birokrasi. Selain itu juga seorang Humas harus dapat membuat opini dan citra baik di mata masyarakat. Hal ini diperkuat dengan fungsi Humas menurut Harlow dalam Danandjaja (2011:103) yaitu mengabdi pada kepentingan umum, memelihara komunikasi yang baik dan menitikberatkan moral dan perilaku yang baik berkenaan dengan profesionalisme pekerjaan.

Dalam kaitannya dengan program SPBS pada tahun 2012 ini, fungsi Humas Pemkab Sumedang telah berhasil mengkomunikasikan nilai-nilai SPBS dalm bentuk sajian buku profil selayang pandang Kabupaten Sumedang yang memuat tentang aplikasi budaya beserta tata kelola pemerintahannya, laporan-laporan kegiatan SPBS melalui majalah mangle, siaran berbahasa Sunda di Radio
Pemda, Penerbitan buku tentang lelucon-lelucon Sunda yang ditulis oleh Inohong Sumedang dan diterbitkan oleh Pemkab. Unggulan SPBS lainnya pada tahun 2012 adalah telah terselesaikannya gedung induk pemerintahan atau pendopo Pemerintah Kabupaten Sumedang sebagai implementasi filosofi budaya Sunda yaitu berbentuk julang ngapak dari sisi interior dan eksterior.

Selain itu, fungsi Humas Pemkab Sumedang dalam program SPBS lainnya dalam diseminasi informasi program berbicara dengan bahasa Sunda seharian sehingga akan tercapainya sasaran pemeliharaan bahasa, sastra dan aksara Sunda malalui:

a. Terwujudnya kurikulum pendidikan bahasa, sastra dan aksara Sunda di sekolah dan kurikulum pendidikan luar sekolah; 
Edutech, Tahun 13, Vol.1, No.1, Februari 2014

b. Terwujudnya kehidupan berbahasa Sunda yang lebih baik dan bermutu;

c. Terwujudnya apresiasi masyarakat terhadap bahasa, sastra dan aksara Sunda;

d. Terwujudnya peran serta masyarakat dalam upaya pemeliharaan bahasa, sastra dan aksara Sunda.

Dilihat dari keberhasilan dari seorang Humas Pemerintah yang handal, yaitu dapat membawa perubahan yang nyata di instasinya, sebagai pembaharu informasi dan bertindak sebagai opinion leader. Oleh karena itulah, peran serta fungsi Humas dalam pemerintahan juga dapat kita lihat dari suksesnya program atau kebijakan yang telah dibuat oleh pemerintah itu sendiri. Suksesnya tersebut terlihat dari masyarakat yang menerima apa yang telah menjadi

keputusan

pemerintah dapat dilaksanakan atau tidak, sehingga dengan demikian Pemerintah pun dapat mempertimbangkan aspirasi dari masyarakatnya sebagai rujukan

perencanaan komunikasi selanjutnya agar berjalan dengan efektif.

Program lainnya dari SPBS yang dikomunikasikan oleh Humas Pemkab Sumedang adalah mengenai kampanye penggunaan baju adat dan ragam hias Kasumedangan sebagai pakaian dinas yang wajib dipakai oleh segenap aparatur di lingkungan pemerintah Kabupaten Sumedang dalam melaksanakan tugasnya pada hari-hari tertentu, seperti digunakan pada saat penyambutan upacara Hari Jadi Kabupaten Sumedang pada tanggal 22 April setiap tahunnya. Adapun tujuannya adalah 1) Melindungi, mengamankan dan melestarikan 
Edutech, Tahun 13, Vol.1, No.1, Februari 2014

keberadaan pakaian adat dan ragam hias Kasumedangan sebagai tinggalan budaya Sunda di Kabupaten Sumedang; 2) Meningkatan kesadaran dan apresiasi masyarakat terhadap penggunaan pakaian adat dan ragam hias Kasumedangan; 3) Meningkatkan pemahaman bahwa penggunaan pakaian adat dan ragam hias Kasumedangan merupakan karya budaya yang menjadi jati diri dan perlambang kebanggaan daerah dan masyarakat Sumedang; 4) Membangkitkan semangat kebersamaan, cinta tanah air, nasionalisme dan patriotisme; 5) Membangkitkan motivasi, memperkaya inspirasi dan memperluas khasanah bagi masyarakat dalam berkarya di bidang kebudayaan;

$$
\text { Program kampanye }
$$

Humas akan berjalan baik apabila Bagian Humas memiliki perencanaan yang matang dalam setiap tindakan yang akan ditempuhnya. Langkahlangkah model perencanaan Humas dalam dunia pemerintahan mengacu pada Management by Objective (MBO) yang meliputi:

a. Penentuan Klien; Apa tujuan dilakukan komunikasi dalam menentukan kebijakan publik dan pelayanan publik, dan bagaimana mencapai tujuannya? Tujuan khususnya seperti membuta kesadaran rakyat atau masyarakat tentang kebijakan publik dan pelayanan publik.

b. Penentuan

Khalayak/Publik;

Bagaimana mengetahui karakteristik rakyat atau masyarakat, dan bagaimana informasi demografis digunakan untuk membuat struktur pesan. 
Edutech, Tahun 13, Vol.1, No.1, Februari 2014

c. Penentuan tujuan Publik; Apa yang ingin publik ketahui dan bagaimana menyampaikan pesan kepada publik yang sesuai dengan keinginan mereka.

d. Penentuan sasaran saluran Media:

Memahami keinginan dari media seperti apa, dan memahami publikasi apa yang akan menjadi daya tarik.

e. Saluran Media: Bagaimana dapat menggunakan multisaluran yang dapat memperkuat pesan diantar publik-publik kunci.

f. Penentuan sumber dan pertanyaan: Siapa yang menjadi sumber informasi utama dan sekunder? Siapa yang diwawancarai? komunikasi; Apakah faktor lingkungan memengaruhi penyebaran dan penerimaan pesan? h. Penentuan esensi Pesan; Apakah komunikasi yang direncanakan memengaruhi publik?

i. Dukungan Nonverbal; Bagaimana fotografis, grafis, artwork dapat memperjelas dan memperindah visualisasi pesan tertulis.

Salah satu contoh dari peran dan fungsi Humas Pemerintah di Indonesia dapat kita lihat melalui kegiatan, penguasaan informasi merupakan syarat mutlak bagi praktisi kehumasan (PR) sekarang ini, dalam mengemban tugasnya di dalam suatu organisasi, baik kedalam maupun ke khalayak luar, informasi merupakan masukan yang harus dikuasai atau dimiliki. Selain itu juga, Humas Pemerintah selalu dituntut kemampuannya dalam menghadapi tantangan dan perubahan lingkungan yang sangat cepat. Sebagai sebuah 
Edutech, Tahun 13, Vol.1, No.1, Februari 2014

kegiatan komunikasi, humas juga berfungsi sebagai jembatan untuk membangun suasana yang kondusif dalam kerangka "win-win solutions", antara berbagai stakeholder organisasi, baik internal dan eksternal untuk membangun citra dari organisasi pemerintahan itu sendiri. Keberadaan Humas tidak dapat dipisahkan dari kegiatan dan opini publik. Termasuk karena pada era sekarang ini, masyarakat sangat menuntut adanya transparansi terhadap apa yang dilakukan oleh pemerintah.

Dengan merujuk pada pendapat Denny Griswold dalam Danandjaja (2011: 2021) adalah hubungan masyarakat merupakan suatu fungsi manajemen yang menilai sikap publik, menunjukkan kebijaksanaan dan prosedur dari seseorang atau sebuah organisasi atas dasar kepentingan publik, dan merencanakan serta menjalankan rencana kerja untuk memperoleh pengertian dan penerimaan yang baik dari publik.

Melihat peran dan fungsi Humas Pemkab Sumedang dalam menjalankan program kampanye SPBS telah sesuai dengan fungsi manajemen Humas dalam suatu organisasi, khususnya di instansi pemerintahan yaitu yang dibuktikan dalam melaksanakan tugas dan perannya selalu berkoordinasi dan bekerjasama dengan bagian lainnya di Setda Pemkab Sumedang dan instansi lainnya dengan membentuk Tim Akselerasi Pengembangan Sumedang Puseur Budaya Sunda, Satuan Tugas (Satgas) dan Kelompok Kerja (Pokja) diantara Setda Pemkab Sumedang dengan Bappeda dan MUI Kabupaten Sumedang.

Fungsi humas pemerintahan perlu diperkuat, karena humas tidak lagi sematamata mensosialisasikan 
Edutech, Tahun 13, Vol.1, No.1, Februari 2014

kebijakan institusi dan membangun serta

mempertahankan citra instansinya, akan tetapi diharapkan berfungsi sebagai Center Information Officer bagi publiknya dan fungsi intelejen dari lembaganya.

\section{SIMPULAN}

\section{Kesimpulan}

Berdasarkan hasil penelitian dan pembahasan diatas dapat dikatakan bahwa hasil penelitian ini dapat dikatakan telah menjawab pertanyaan penelitian yang diajukan, sehingga penulis dapat menyampaikan simpulan atas hasil penelitian sebagai berikut:

a. Latar belakang diadakannnya program Sumedang Puseur Budaya Sunda (SPBS) yang telah ditetapkan oleh Pemerintah Provinsi Jawa Barat pada tahun 2009 telah sesuai dengan nilai-nilai kebudayaan dan potensi yang dimiliki oleh Pemerintah Kabupaten Sumedang dalam hal budaya Sunda seperti wisata kuliner, situs sejarah, atraksi budaya, dan kriteria lainnya yang sesuai dengan kriteria-kriteria yang telah ditetapkan dalam Peraturan Bupati No.113 Tahun 2009.

b. Secara struktur organisasional kedudukan Humas Pemkab Sumedang berada di bawah Setda Pemkab Sumedang dan sudah berada dalam keadaan berdiri sendiri dan bertanggung jawab kepada Asisten Bidang Pemerintahan Setda Pemkab Sumedang bertugas dalam hal pengelolaan data dan sistem informasi, dokumentasi serta pengelolaan pemberitaan mengenai kebijakan Pemkab kepada masyarakat dan media, khususnya mengenai sosialisasi program SPBS. Adapun peran Bagian Humas Pemkab Sumedang dalam mengkampanyekan program SPBS telah berjalan dengan baik, yang 
Edutech, Tahun 13, Vol.1, No.1, Februari 2014

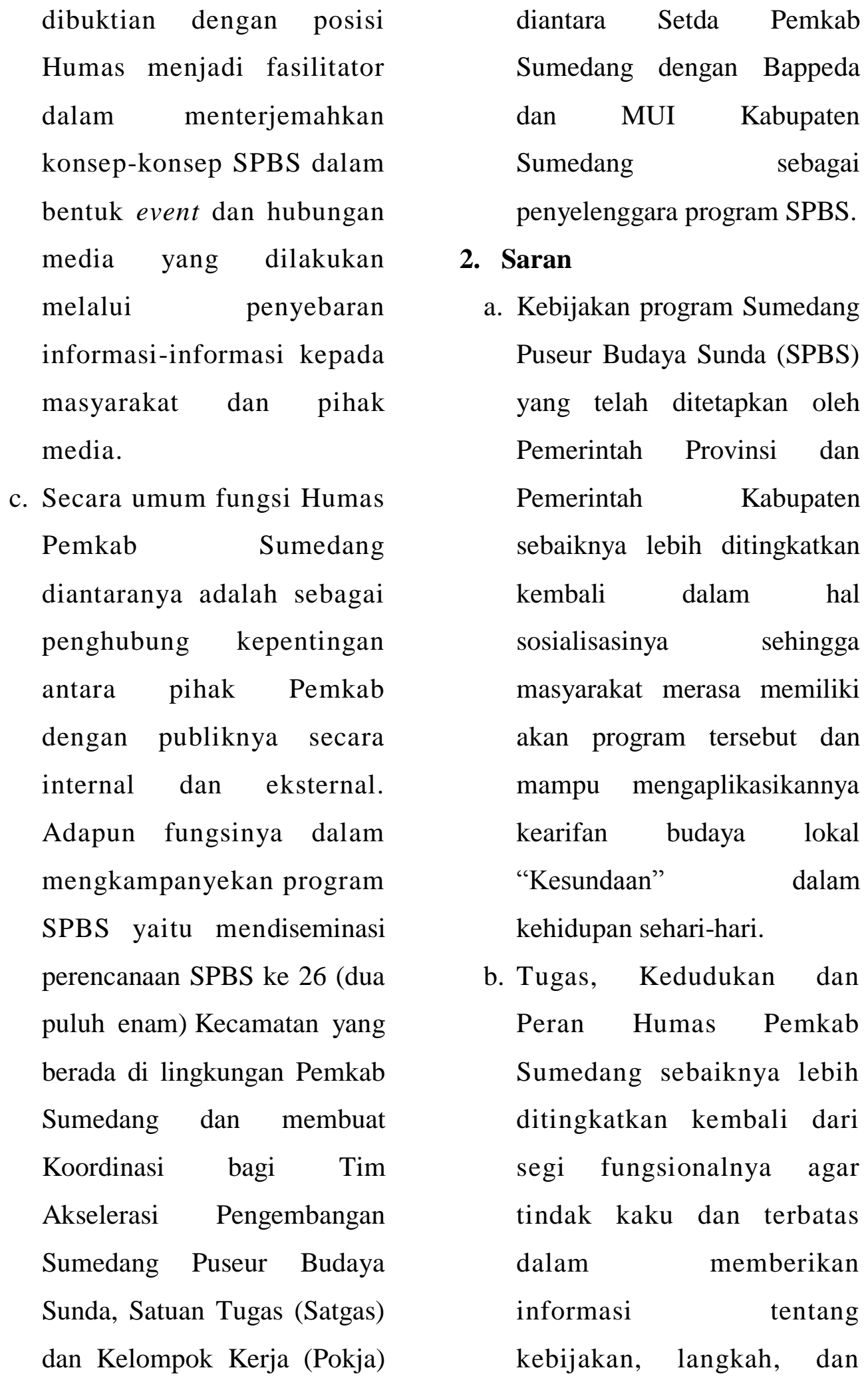


Edutech, Tahun 13, Vol.1, No.1, Februari 2014

tindakan pemerintah; menguasai bidang lainnya memberi bantuan informasi apabila diperlukan.

kepada media massa;

D. DAFTAR PUSTAKA

mempromosikan

perkembangan ekonomi dan

budaya bangsa; dan memonitor opini publik.

c. Fungsi Humas Pemkab

Sumedang secara umum telah berjalan dengan baik, namun perlu adanya peningkatan kualitas dan peningkatan sarana dan prasarana yang menunjang pada kegiatan fungsi Humas tersebut. Adapun dalam mengkampanyekan program SPBS, fungsi Humas Pemkab Sumedang sebaiknya dilakukan lebih optimal melalui peningkatan kualitas dan kuantitas SDM, yaitu dengan mempekerjakan seluruh anggota di divisi Humas untuk bekerja dengan efektif, maksudnya satu orang yang memiliki keahlian dan kekhususan di bidang tertentu harus dapat

Profesi Kehumasan Serta Aplikasinya di Indonesia. Jakarta: Bumi Aksara.

Ardianto, Elvinaro dan Soleh Soemirat. 2003. Dasar-Dasar Public Relations.Bandung: PT Remaja Rosdakarya.

Ardianto, Elvinaro. 2004. Public Relations Suatu Pendekatan Praktis. Bandung: Pustaka Bani Quraisy.

Cutlip, Scoot M., Allen H. Center, and Glen M. Broom, 2000. Effective Public Relations, Eight Editions, Prentice Hall Inc., New Jersey.

Danandjaja. 2011. Peranan Humas dalam Perusahaan. Yogyakarta: Graha Ilmu

Effendy, Onong U. 1992. Hubungan Masyarakat Suatu Studi Komunikologis. Bandung: Penerbit PT Remaja Rosdakarya. Fombrun, Charles J. 1996. Reputation: Realizing Value from the 
Corporate Image. Boston:

Harvard Business Shool Press.

Kasali, Rhenald. 1994. Manajemen Public Relations, Konsep dan Aplikasinya di Indonesia, Jakarta: Pustaka Utama graffiti.

Mulyana, Deddy. 2001. Nuansanuansa Komunikasi. Bandung: Remaja Rosdakarya.

Rakhmat, Jalaluddin. 2004. Metode Penelitian Komunikasi. Bandung: Remaja Rosdakarya.

Ruslan, Rosady.1997. Kiat dan Strategi Kampanye Public Relations. Jakarta: Grafindo.

Setyaningrum, Shanti. 2008. I am a Public Relations: Living It \& Loving It. PT. Niaga Swadaya Suryabrata, Sumadi. 1998. Metodologi Penelitian. Jakarta: PT. Raja Grafindo Persada

Tondowidjojo, John. 2004. Dasar dan Arah Public Relations. Jakarta: PT. Grasindo.

Venus, Antar.2004.Manajemen Kampanye. Bandung: Simbiosa Rekatama Media. 